\title{
Displacement and the Quest for Identity in Alain Gomis's Cinema
}

Estrella Sendra

\section{Abstract}

In this essay, I seek to explore the cinema of Alain Gomis through a focus on his depiction of displacement. I particularly examine three of his films where various forms of displacement occur, L'Afrance / As a Man (2001), Andalucia / Andalusia (2007), and Tey / Today (2012), in order to show that they share a similar aesthetic approach. I argue that Gomis's aesthetic approach is marked by intimacy and embodiment, which are strategies employed within the rich Senegalese film heritage in general. Gomis's cinema is multi-sensorial. Its narrative is the result of a combination of visual and aural elements, which also suggest an investment in the haptic. Through this unique approach Gomis engages in a representation of displacement whose resolution is questionable, as it is shaped by a strong psychological component. The displacement experienced by the characters of his films leads to disturbing situations in which the protagonists find themselves questioning their identity. This quest is hard to accept, particularly when it leads to the realization that displacement, as a psychological state of being, may never end.

Alain Gomis is arguably one of the leading filmmakers of the twenty-first century and has won numerous awards on the international film festival circuit including two Golden Yennenga Stallion awards at the Pan-African Film and Television Festival of Ouagadougou (FESPACO), and the Best African Film, among other awards, ${ }^{1}$ at the African Movie Academy Awards (AMAA) 2017 for his fourth feature-length film Félicité (2016). Born in 1972 in Paris to a Senegalese father originally from Guinea Bissau and a French mother,

Gomis has had a prolific and internationally acclaimed career. ${ }^{2}$ Despite numerous reviews 
and articles of his films published in the media, no scholarly, peer-reviewed articles or books have been published on his film trajectory to date. ${ }^{3}$ The only mention of one of his films, L'Afrance / As a Man (2001), appears in the article "Subjects of Exile: Alienation in Francophone West African cinema" by Lindiwe Dovey. ${ }^{5}$

Dovey selects several West African films that explore the concept of alienation yet embody a point of view grounded within Africa, such as Ousmane Sembène's La Noire de... / Black Girl (1966, from Senegal), Djibril Diop Mambéty’s Touki Bouki (1973, from Senegal), and Abderrahmane Sissako's Heremakono / Waiting for Happiness (2002, from Mali and Mauritania). This choice integrates Africa in Francophone Studies and acknowledges a dual dimension of exile, which is not just 'external' (bodily) but also 'internal' (psychological). Dovey emphasizes the latter, identifying it as 'alienation,' which refers to the psychological effect caused by 'exile,' meaning "the action of separation." article compares the aesthetic approach of the films, and defines this as a 'palimpsestic' or superimposed aesthetic, ${ }^{7}$ reflective of the different layers and complexity of exile. The films embody a criticism of the home country that Dovey suggests is shaped by the international film careers of their filmmakers. ${ }^{8}$ She claims that the films prove that alienation can be felt both abroad - when one is physically displaced from home and psychologically affected by that displacement - and at home, due to disagreement with or critical attitudes towards oppressive practices in one's home country. ${ }^{9}$ Dovey thus draws on Julia Kristeva's view that we are all somehow "strangers to ourselves." 10

This essay borrows from Dovey's previous analysis of exile in francophone West African films, drawing particularly on her consideration of the psychological and physical dimensions of exilic experiences. Expanding on Dovey's ideas about alienation, I analyze transnational displacement more broadly, including As a Man as well as Gomis's two later films, Andalucia / Andalusia (2007), and Tey / Today (2012). Through a focus on three of 
Gomis's films, As a Man, Andalusia and Today, I argue/posit/claim... Through a comprehensive examination of these three films, I seek to fill a gap in film scholarship by establishing a foundation for studies of Gomis's cinema. I focus on Gomis's filmography and filmmaking aesthetics, examining the uniqueness of his portrayal of displacement. The aesthetics of Gomis's films have been profoundly influenced by those of Mambéty, noted also by film critic Olivier Barlet, who refers to the use of professional and non-professional actors and "dreamlike visions." 11

I begin with an understanding of Gomis as a 'rooted cosmopolitan, ${ }^{12}$ borrowing Kwame Appiah's term. ${ }^{13}$ Gomis was born and raised in France, which is also where he completed his studies. His films, shot in France, Spain, Senegal in collaboration with international producers and filmmakers, such as Newton Aduaka (from Nigeria, based in the United Kingdom), have been made and screened internationally. This life experience and film career make Gomis a 'cosmopolitan,' a citizen of the world. Yet Gomis is also a filmmaker psychologically rooted in Senegal and this appears as the reference to 'home' in the three films I analyze here. This is because Gomis is not simply a cosmopolitan, but a 'rooted cosmopolitan' in that he is a citizen of the world but feels rooted and engaged with Senegal and other areas in the world where he has lived, travelled to, or worked. Borrowing Appiah's words, Gomis feels "responsible solidarity with all humanity," but as a "patriot of Africa," he also "intensely engages with many narrower, overlapping communities,"14 and notably, with his Senegalese roots. A 'rooted cosmopolitan' is also someone with a motivation to "give back," to contribute to the world, by "making some local place better," even if this is not the birth place. ${ }^{15}$

In his cinema, Gomis encourages reflection about realities faced by people across the world, focusing particularly on displacement and its implications. He has also become an 'ambassador' of and source of pride for Senegalese cinema through his internationally 
successful film career. This has not just been acknowledged by Senegalese president Macky Sall, ${ }^{16}$ but by young filmmakers, cinephiles and cultural actors in Senegal, with whom Gomis has been exchanging throughout his film trajectory. ${ }^{17}$ Because of his physical position outside of Senegal and the resulting critical distance, he is favorably placed to tackle the complexities of displacement. Like Kristeva and Dovey, Gomis sees that the situation of displacement can trigger more evidently the quest for identity that is intrinsic in all of us. It can also stress the feeling that we are strangers to ourselves, as experienced by the characters of his first three feature-length films.

As a filmmaker based physically in France, but also partly psychologically in Senegal, Gomis's cinema could be analyzed through Hamid Naficy's concept of 'accented cinema.' This kind of cinema contrasts with that produced through the homogeneous Hollywood studio system in that it features displaced characters. However, the accent does not refer so much to the characters' speech but to the experience of displacement by the diasporic or exilic filmmaker, which shapes the film narrative, aesthetics, and style. ${ }^{18}$ Naficy argues that the style of accented films is fragmented, multilingual, epistolary, nostalgic, and is composed of characters who feel lost, who are involved in travelling, and who are dealing with identity issues triggered by displacement. The best of these films, he suggests, "signify upon exile by ... commenting upon, and critiquing the home and host societies and cultures.” These styles and themes can be applied to Gomis's films, whose narratives emerge from displacement experienced by the filmmaker himself, as a 'rooted cosmopolitan.' The psychological accent of his films is evident in As a Man, whose original title is L'Afrance. This merges France (in French, La France) with Africa (L'Afrique), not physically, but psychologically. It could be associated also with Françafrique, a term with pejorative connotations, suggesting France's neocolonial relationship with 'independent' African countries that were under its colonial rule. At the same time, it implies the A-France - the "no 
France" - that is, the unknown France, in contrast with the representation of it as El Dorado that encourages people to migrate.

Gomis's fragmented style, with changes of rhythm, time, and space, resonates with the accented cinema style. As Barlet shrewdly observes, Gomis places uncertainty as the founding principle of his films. ${ }^{19}$ He puts spectators in an area of "discomfort, where references are absent, where the length is different, but where feelings that could not arise from a constrained storyline emerge." 20 Their characters are, as in the case of accented cinema, multilingual. They shift from one language to another, among their repertoires of languages, depending on the situation and where the character is psychologically emplacing himself. That is, through language the characters temporarily situate themselves in different spaces or sets of relations within this broader condition of displacement. For example, in As a Man, El Hadj, a Senegalese immigrant in France, speaks mainly in French, even with Awa (his long-time girlfriend who has remained in Senegal). However, there are moments during his conversations with Awa in which he shifts to Wolof, particularly when there is miscommunication between them, not so much linguistic, but due to El Hadj's difficulties in empathizing with Awa, who awaits his return. The shift to Wolof in this case represents the two different ideological universes in France and Senegal. While Senegal is a francophone country, with French as the official language, the origins of French are colonial. The use of Wolof during a situation of conflict within an interaction that is generally happening in French operates as a reference to the French colonization of Senegal, whose consequences are still faced decades after independence. The characters are dealing with identity issues, and there are significant nostalgic moments, which also define the style of accented cinema. However, describing Gomis's cinema merely as accented may conceal the uniqueness of his authorial style, as accented cinema stresses the consistent use of certain philosophical tendencies and aesthetic concerns across several directors. ${ }^{21}$ 
Gomis's cinema can also be examined through the concept of 'intercultural cinema,' which, according to Laura Marks, emerges mainly from displaced authors based in Western metropolitan centers, and contrasts with mainstream cinemas from modern Euro-American societies. $^{22}$ This is characterized, she suggests, by “experimental styles that attempt to represent the experience of living between two or more cultural regimes of knowledge, or living as a minority in the still majority white, Euro-American West." ${ }^{23}$ It can then be applied to Gomis, as a French-born citizen of a French mother and a Senegalese father, and whose films draw on experiences of displacement. Senegal appears as an explicit reference in the case of Today and As a Man, and as an indirect reference in the case of Andalusia. Like Naficy in the case of accented cinema, Marks also notes that the style of intercultural cinema is fragmentary, moving "backward and forward in time." ${ }^{24}$ That is, there are flashbacks and scenes imagined in the future that are connected through an experimental poetic editing, where the lack of linearity reflects the psychological state of the characters. Through examples of Gomis's three cited films, I seek to further address the fragmentary style and temporal flashbacks in relation to space. I examine the ways in which Gomis uses space to think about displacement and its endless nature.

I suggest that As a Man, Andalusia, and Today share the common feature of depicting male protagonists in situations of displacement which leads to a quest for identity and consequent internal struggles. Displacement is also a concept tightly linked to the idea of home, as a result of the separation from it, which involves both a physical and a psychological dimension. As Gomis puts it:

When we live outside of our country, we live with an image of a souvenir that eventually becomes a little fixed over time. What is difficult is that when you leave the everyday, your country keeps evolving, but you remain in a period a bit past. So there is a sort of separation that happens like that. For me, it was important to show in this film the relation between a dreamed country and those little things that will make it impossible to return. I mean, you can return physically, but the country that you left no longer exists, by force. It has evolved. I wanted to talk about that, which is in a way a form of 
injustice for immigrants, who already have the difficulty of living far but additionally, there is a feeling of losing something tangible with their country. ${ }^{25}$

I analyze the aesthetics of Gomis's three films and the way they contribute to his portrayal of the non-closure of displacement. I argue that the idea of the return is presented as a potential solution of the situation of displacement but appears both as a dream and an impossibility. Gomis's statement is particularly revealing of the importance of the psychological dimension of displacement. It involves a 'before,' that is, a past situation that precedes the present situation of displacement, the latter being physical, psychological, or both. The reference to home, as an idea and ideal, belongs to the past, and appears in the present nostalgically, as a memory. Gomis's statement also shows that displacement extends over time, psychologically, even if there is a physical return. Finally, this quote serves to support my view of Gomis as a 'rooted cosmopolitan,' moved to speak about the complexities experienced in displacement and to claim the injustice faced by displaced subjects.

I suggest that Gomis's aesthetic approach is characterized by intimacy, and embodiment, in particular, through stimulating the aural and haptic. In this way, I draw on Kate Bolgar Smith's doctoral dissertation on soundtracks of films that address black diasporic life in London and Paris, where she refers to the importance of sound and silence in Today. ${ }^{26}$ Her study moves away from the visual bias in film scholarship to focus on the aural, stressing the ability of sound to illustrate different ideas of place and belonging. Inspired by her focus on the aural elements, I do not only focus on music, like she does, but on other kinds of aural elements, including silence, as non-visual resources to suggest displacement. I refer to Dovey's concept of 'palimpsestic aesthetics,' which she uses to refer to the superimposed aesthetic of francophone West African films; ${ }^{27}$ and Marks's notion of 'haptic visuality,' which refers to the capacity of vision to evoke the tactile sense. ${ }^{28}$ I suggest that such an aesthetic approach is key to emphasizing the psychological dimension and hence on-going 
nature of displacement, superseding the filmic resource of the subjective camera, and further achieving an internal focalization illustrative of the multidimensional and dynamic aspect of identity.

Before delving into the aesthetic approach, it is worth mentioning the reason why I identify displacement as a revolving theme in Gomis's cinema. Olivier Bakewell's conceptualization of displacement and migration in relation with each other helps to illustrate the relevance of the choice of the notion of displacement. Bakewell distinguishes this from migration when these are considered as a process, condition, or category. When understood as a process, displacement and migration are difficult to distinguish, as they both are, like exile, social processes which involve mobility. ${ }^{29}$ Yet, when understood as a condition, by which Bakewell refers to a "state of being," migration and displacement are distinct. The difference is that while the process (the physical movement) finishes, the condition prevails, ${ }^{30}$ as implied by Gomis in his statement quoted above.

It is Bakewell's understanding of both concepts as a condition that is particularly helpful for this essay, and underlines my choice of displacement to approach the themes in Gomis's cinema. For Bakewell, migration refers to a past, fixed event which is easy to locate, that makes someone identifiable (and able to be categorized) by others as a migrant. Displacement, in contrast, is a "continuous state of being. ... [U]nlike being a migrant, the condition of displacement does not become fixed with the end of the movement; it remains an ongoing condition and feeling which is concerned with a separation from 'home."' It is a "subjective condition," which may be "maintained over time and reproduced through generations." 31 That is, displacement can be experienced without the necessity of physical movement. This is exactly what happens to Yacine in Andalusia. Yacine is a French-born citizen of Algerian heritage unable to settle and feel at ease in Paris. His internal struggle 
suggests a need to return to his native or ancestral land, even if he has never lived there physically.

Displacement appears as a concept opposed to emplacement. Displacement, Bakewell suggests, "comes to an end" when one returns home or finds a place to settle, a new 'home.'32 This is an idea I challenge through the analysis of the use of space, sound, and touch in Gomis's films. The internal struggle is exposed, and reflected upon, but remains unresolved in all three films. The openness of displacement has to do with the multifaceted nature of identity, emphasized in situations of displacement, as noted by Gomis. June Givanni argues that the situation of mobility across different cultures necessarily implies a process of transformation among people in such situations. ${ }^{33}$ Similarly, both Ernesto Laclau and Stuart Hall emphasize the "decentered" position ${ }^{34}$ of any social subject, whose "identity is nothing but the unstable articulation of constantly changing positionalities." ${ }^{35}$ Identity is a dynamic process, shaped by social encounters and life experiences, and as such, it is in continuous transformation, as masterfully illustrated in Gomis's films.

Like Dovey, who prefers alienation over exile to stress the psychological dimension of the latter, I prefer displacement over migration. Displacement, understood as condition, also emphasizes the psychological dimension of mobility, more than the term migration. It also covers broader transnational forms of external mobility than the term exile. As Angelika Bammer claims, displacement refers to "the separation of people from their native culture either through physical dislocation (as refugees, immigrants, migrants, exiles, or expatriates) or the colonizing imposition of a foreign culture," which she sees as a universal experience among people in the twentieth and twenty-first century. ${ }^{36}$ Displacement is a concept illustrative of the complexities involved in different forms of mobility and the feeling of being a stranger even to oneself. 
All three films feature male characters in conditions of displacement, experienced differently in each of the films. In As a Man, El Hadj is a Senegalese student who, despite having been based in France for over a decade, still feels like a stranger. ${ }^{37}$ He also struggles because he feels a duty to return to Senegal, but realizes he will be a stranger after his return, due to his experience of displacement. In contrast, in Andalusia, Yacine was born and has lived in France for his whole life, but still feels like a foreigner because of his Algerian heritage. He was already born in the condition of displacement, inherited from at least one generation. He only finds a sense of ease at the end of the film when travelling, not 'back,' but to Toledo in Spain. Once there, he identifies himself with the features of his ancestors in the different paintings of El Greco. This takes him to Granada, in Andalusia (Southern Spain), where he seems to feel free, as if he has found a home there, an emplacement, even if this also may be temporary. A different depiction of displacement appears in Today. The main character, Satché, has already tried to "end" the situation of displacement. The film starts once he has returned to Senegal, after living for many years in America. Yet he keeps feeling lost after a year of return, implying that displacement has not been resolved. Satché may be physically "back," yet he keeps experiencing a form of psychological displacement because, as Naficy notes, "it is possible to be in internal exile and yet be at home." 38 The film questions the possibility of a permanent resolution of displacement, as this is both internal (psychological) and external (bodily or physical).

\section{Displacement as Heterotopia}

Gomis's films challenge the idea that displacement concludes through the return (to the native or ancestral land) or the emplacement in a new home. Displacement, as a condition or "state of being," persists, in that it is not just a physical phenomenon that entails mobility, but a psychological one that shapes the displaced subjects. Each of the characters in the films shares the feeling of never being home. They all live in a permanent state of confusion and 
internal struggle. The non-closure of displacement is illustrated in Gomis's film through space. The kind of space inhabited both internally and externally by the displaced subjects featured in each of his films can be analyzed through Michel Foucault's notion of 'heterotopia.'39

Michel Foucault characterizes the present epoch as "the epoch of space ..., simultaneity, ... of juxtaposition, ... of the near and far, of the side-by-side, of the dispersed." 40 The space in which we live, Foucault argues, is heterogeneous and composed of a set of relations. ${ }^{41}$ The notion of 'heterotopia' is adopted by him in contrast to utopia (sites with no real places), designating a kind of place whose uniqueness is that it comprises a set of "real sites than can be found within the culture, are simultaneously represented, contested, and inverted." 42 What is particularly interesting for the argument made in this essay is that heterotopias are "outside of all places, even though it may be possible to indicate their location in reality." 43 In other words, heterotopias, like displacement, cannot be reduced to a single location. They merge different relations, places, and experiences, at times incompatible, that result in a complex setting in a single real place.

In Gomis's films, the protagonists are psychologically in several spaces at the same time, or in none of them, or rapidly alternating between one and another. In As a Man and Andalusia, characters find themselves in a heterotopia that consists of a juxtaposition of several places and countries in a real space and time. The heterotopia is also an in-between space, where characters never have the feeling of being home, as this is an ideal that belongs to the past.

The depiction of displacement as heterotopia is evident from the very beginning of $A s$ a Man, where shots of the streets of Dakar, with the iconic images of the 'car rapides' (the colourful public transport decorated with Sufi brotherhood leaders, verses and phrases), intertwine with shots of Paris. The protagonist, El Hadj, has continuous flashbacks to his 
youth in Dakarwhen he studied Cheikh Hamidou Kane's novel on displacement, L'aventure ambigue / Ambiguous Adventure, which reminds him of his own experience in France. Similarly, in Andalusia, Yacine also has flashbacks to his childhood when he coincidentally encounters an old friend from that time of his life. The poetic montage of the three films transports us to the internal universe of the psychology of the characters, embracing the synthesis of times and spaces that displacement entails.

Today is also an illustrative example of the ongoing and heterotopic nature of displacement and the impossibility to resolve it even when the place where the character is physically located is 'home.' While the film title is a temporal reference to the present, today, space plays a central role in the depiction of a kind of displacement grounded in Africa, where it is also possible to feel alienated, that is, like a stranger. The film tells the story of Satché, a young man who wakes up confused one day, as God has spiritually announced that it will be his last day on earth. This takes Satché through an exploration of his life journey, questioning what he has achieved, if anything at all. The immersion in the past is not biographical, as Barlet notes, ${ }^{44}$ but intimate, in that it is psychological, and involves also the space in which he is currently based, Senegal, and the place from where he has returned, the United States of America. The depiction of Satché's current spatial location, when he wanders around the streets of Dakar, emphasizes his psychological struggle and as such, the persistence of Satché's condition as (internally) displaced. Even though Satché is "back home," he feels alienated.

The city of Dakar is shown in a state of tension. This is reflected within the film when Satché is confronted by his friends. They ask him about the reason why he has returned, to which Satché replies with silence. In his analysis of the film, Barlet suggests that our world is shaped by the loss of references, due to the economic and ecological crisis, which leads to an "in-between state," a "state of vacillation, of unease, of anxiety." He further claims that 
this has largely been experienced by Africans due to the colonization of their countries, creating uncertainty about people's future..$^{45}$ Dovey adds that the double alienation also results from "neo-colonialism and the continuation of certain oppressive pre-colonial African traditions." 46 These ideas are reinforced in Today through a representation of the space of Dakar as a 'ghost' of its colonial period, with colonial buildings in ruins. This feature could be seen as inherited from the cinema of Mambéty, whose depiction of Dakar was of a city in continuous transition, seeking "to free itself from the colonial shadow," still palpable through its space. ${ }^{47}$ This idea is further stressed in Today through a tension that supersedes the fictional boundaries of the film, including images from a citizen movement happening during the electoral period in which the film was shot, demanding change, as I discuss below. [Sendra_Figure 01]

The state of abandonment of Dakar and of the internal alienation it can foster even for people based in Senegal is implied through a scene of Satché and his friend Sélé walking for no apparent reason at the ancien Palais de Justice, a courthouse that was built in 1958, during the colonial period, and that later hosted the contemporary art exhibition at the Premier festival mondial des arts nègres (First World Festival of Negro Arts) in 1966, a pan-African festival of international relevance celebrated under the patronage of first president of Senegal, Léopold Sédar Senghor. ${ }^{48}$ However, it was abandoned years later and unoccupied for decades. The space of the ancien Palais de Justice in the film merges different temporalities in the real site of the abandoned, static building where Satché and Sélé are walking, juxtaposed with their movement. In other words, there is a rhythmic contrast between the population of Senegal and the politicians' rule, illustrated through this scene. The space represented constitutes a heterotopia. It could also be seen as a 'palimpsest' (using Dovey's term to refer to the aesthetic of exilic francophone West African films), illustrative of the multidimensional aspect of displacement, and its non-closure at the psychological level. 
This is further illustrated through the choice of including shots of a non-fictional historic event that occurred in Dakar during the shooting of Today. The tension reflected by the fiction of the narrative dovetails and intertwines with the actual tension in the streets of Dakar, as the citizen's movement Y'En a Marre (We are Fed Up) was taking the streets during the presidential elections of 2012. The demonstrations, peaceful yet charged with tension, were led by rappers and journalists. The local Senegalese population joined the movement to,pagainst Abdoulaye Wade, president for twelve years, who wanted to unconstitutionally run for a third term. ${ }^{49}$ The film includes non-staged shots of the protests, complemented by close-up shots of women expressing that they are fed up with Wade and the situation in their country. Their immersion in the fictional narrative reinforces the idea that alienation can also be felt within the homeland, through dissatisfaction and disagreement with a system where colonization remains palpable in the present, and is manifested spatially. These spatial references in Today prove that displacement is not necessarily located in a particular place, often considered as a foreign location ,outside of the home country. Furthermore, displacement is not necessarily resolved by moving one's base somewhere else, to a certain place associated with the homeland. Alienation can happen both in the 'host' land and the homeland. ${ }^{50}$

In Andalusia and As a Man, France represents the 'alien-nation.' ${ }^{51}$ Gomis represents it as a hostile space through night shots in which the main characters, Yacine and El Hadj, respectively, feel threatened. The two films stress the psychological dimension of displacement as a "state of being" that does not cease even after a long period of residence in France, in the case of El Hadj; or even if Yacine has been born in France. They can physically be based in France, but their psychological location keeps shifting and shapes the ways in which they live, interact with others, and navigate the city of Paris . This is masterfully illustrated from the opening scene in As a Man, whose original title is, as 
mentioned above, an excellent example of the understanding of displacement as heterotopia. [Sendra_Figure 02]

In the film, El Hadj's current situation in France is at odds with his past expectations while still in Senegal. In his present, he is being arrested by the police for trying to renew his passport six days after the expiry date, thus in an 'irregular' situation. This means that he cannot receive the scholarship to finish his thesis, which pushes him to work in construction for survival. He is also in a relationship with a French artist, but at the same time, he is receiving pressure from his family and girlfriend back home, Awa, to return and marry her. In contrast, in the past, he wanted to receive his degree in Paris to then go back to Senegal and teach about history and leaders of the independence struggle. His plan was also to get married with his long-time girlfriend, Awa. Both temporalities further clash with his hopes in the present of going back, maybe just temporarily, despite not having finished the thesis. This leads to a state of confusion, and an internal struggle where El Hadj is undecided about what to do. All these relations constitute the heterotopia in which he exists as a displaced subject. The dilemma further manifests spatially. El Hadj does not interact with the touristic city of Paris nor does he appear to be experiencing the utopia or representation of France as El Dorado. At the beginning of the film, the iconic image of the Eiffel Tower appears in the background, as El Hadj picks up a plastic bird decorated with the colors of the French flag. This is one of the souvenirs sold by his friend, as we see when he then walks next to El Hadj. This is a highly symbolic moment from the very beginning of the film of the alien-nation experienced by the characters who are immigrants from Senegal, a former French colony. However, Senegalese people based in France sell the iconic representation of the colonizer, small, souvenir Eiffel Towers. These are not just sold in France but also brought back to Senegal by migrants for their relatives, along with other souvenirs decorated with the French flag. This use of the iconic space of the Eiffel Tower represents the impossibility of 
psychologically reaching the ideal of France that was articulated in the past, even when physically occupying that space. Gomis also signals in this sequence the perpetuation of the utopic vision of France as the promised land for potential migrants, which translates into an internal struggle for El Hadj and a search of $\mathrm{jamm}^{52}$ through the return to Senegal.

The sense of emplacement does not necessarily imply a return to the native land but a search for rootedness through connections with an unknown ancestral land. In Andalusia, Yacine does not mention a willingness to leave Paris. His departure is motivated by random people who suddenly advise him to take a train and follow a specific direction. He ends up in the museum of El Greco, in Toledo. To his astonishment, he identifies with the look of the people in El Greco's paintings, touching his skin to verify that it matches what he is seeing. This eventually takes him to Andalusia, where he is seen in different locations where he feels certain identification and ease. In contrast with the shots of Paris, marked by hostility, Yacine's happiness is represented through the bright landscapes where he feels such lightness that he can fly, or so he imagines and senses, arguably identifying the 'jamm' his friends had talked about. [Sendra_Figure 03]

The open endings of both Andalusia and As a Man, with the protagonists immersed in nature, imply a certain temporality of the state of apparent ease experienced by the characters. The openness of the films challenges the idea that displacement can ever be completely resolved through a change of geographical location. In other words, emplacement does not seem, in any of the films, a permanent state of being. Similarly, displacement appears as a condition of ambiguous temporality, which eventually leaves, to then come back and manifest itself in a different way. Emplacement and displacement constitute an interdependent binary opposition. That is, emplacement is sought due to a situation of displacement. Since displacement can both be internal and external, and since identity is in constant flux, any sense of emplacement can only be temporary. The openness in Gomis's 
cinema intentionally avoids a dogmatic position, as it is not about the solutions, but about the questions and the reflection on the doubts of a character "trying to go deeper inside them." 53

The synthesis of spaces and ideas associated with them within the real space of France that the characters occupy both in Andalusia and As a Man is also manifested through the creation of micro-home spaces within the films. These micro-home spaces tend to be intimate interior spaces, such as a bedroom. They are also heterotopic in that they transport the characters psychologically to Senegal, even if they are located physically in France. For example, El Hadj's bedroom is decorated with a tapestry from Senegal, wax printed fabric, photographs of his relatives and girlfriend, as well as photographs of independence-era African political leaders, such as Patrice Lumumba, or Sekou Touré, to whom El Hadj refers while reflecting on feeling a duty to return to Senegal.

Similarly, Yacine, in Andalusia, lives in a caravan whose walls are fully covered by a collage of photographs and press clippings that feature images of Tanoura (a Sufi dance from Egypt), and the black American writer and activist James Baldwin. In contrast with As a Man, where references to Senegal are explicit, the photographs, press cuttings, and diverse objects kept by Yacine have different origins. These references in both films supersede the physicality of the photographs in the bedrooms and appear as dreams and imaginations where characters are known through an internal focalization of their psychologies. They represent past expectations for the characters, as well as dreams in the case of As a Man. In Andalusia, the images and clippings make Yacine feel a certain rootedness or effort to find it in the hostility of his alien-nation.

The micro-home spaces can lead to apparent temporary instances of present emplacement. Their perishability is due to the heterotopic and open nature of displacement where the micro-home spaces arise, which extends across time and spaces. However, they operate as instances of emplacement within the real space where characters are based in that 
they generate a sense of ease for the displaced subjects. The lack of ease in displacement is explicitly addressed in a scene in the park in Andalusia. Yacine is chatting with his old childhood friend, Djibril (from Senegal), who he has randomly met again after many years. This encounter leads to the only kind of human interaction where Yacine is able to engage in verbal conversations. One evening, Djibril and another Senegalese friend named Moussa tell Yacine a story whose moral is the importance of 'jamm.' It is then that the unease experienced by Yacine due to his displacement is explicitly acknowledged.

The characters are, however, able to experience certain ease through their creation of micro-home spaces, where 'home' can either refer to Senegal, the host land, or even a new home that suggests a sense of rootedness. In As a Man, a temporary emplacement appears in a house where El Hadj lives with other compatriots. It is a micro-home space where they eat Senegalese food, drink attaya (Senegalese green tea), and where El Hadj is able to talk to peers who understand each other. This environment contrasts with the difficult communication about the hostility experienced in displacement with his family back home. While El Hadj's experiences in France may not correspond to the promised land of which he dreamt when he left, the space in Paris that he shares with other Senegalese people is a sort of new home, between Senegal and France. In this “in-between” space, El Hadj struggles to accept that there may be the possibility of creating a new 'home' out of Senegal, due to the difficulties and racism that he encounters in France.

Beyond the micro-home spaces where he shares ways of living with other people from Senegal, El Hadj finds further moments of temporary emplacement. These occur with Myriam, a French artist with whom he develops a relationship. They meet at the wedding of a Senegalese friend of El Hadj and a French friend of Myriam, and the smooth conversation ends in Myriam's invitation to visit her art studio. The interaction between them at the studio 
is one of the few daylight scenes in the film in which El Hadj appears to sense jamm and hence, emplacement.

However, despite these temporary moments, El Hadj fails to settle in Paris. He does not admit having a relationship with Myriam to his friends and does not fully accept it himself, since he is always planning a physical return. His increasing repetition of the phrase "I must go back" illustrates El Hadj's identity crisis when he realizes his return can no longer happen at the psychological level. This realization puts a strain on his personal relations. His interactions with his Senegalese friends, as well as with Myriam, revolve around the return, leading to tensions. "I must go back", El Hadj tells Myriam. "Why [do you say] must?” To which El Hadj replies, "It is my life. It is why I wake up every morning. I have a life waiting for me there. ... I am tired of being a stranger. ... I am fed up with being black. I am Senegalese." This statement is illustrative of the diversity of aspects that displacement entails. Racist attitudes that "other" him, categorizing him as "black," exacerbate the psychological displacement, the feeling of being in an alien-nation, beyond the physical distance from Senegal.

The internal struggle is also stressed upon the realization and acceptance of the impossibility of his return. In other words, El Hadj starts to notice that the return may not end the situation of displacement. In the same way in which the sense of rootedness appears more psychologically than physically while in Paris, the physical return to Senegal does not necessarily mean the psychological return, since home, like El Hadj, has also changed. As Sarah Jilani puts it, whilst in physical displacement, "home in the immigrant genre is a fiction that one can move beyond or recreate at will ... through the stasis of nostalgia and through the lens of childhood, its dependable and even temporally-arrested state is 'held up to scrutiny and let go." ${ }^{54}$ As a consequence, "it is possible to return and to find that one's house is not the home that one had hoped for, that it is not the structure that memory built." ${ }^{55}$ The 
return appears more as a duty than as a solution to the quest for identity. The characters, like Gomis himself, are 'rooted cosmopolitans,' who while abroad identify themselves with their places of origin, and feel the need to give back to them. El Hadj, for example, wants to go back to Senegal to teach about Sekou Touré, about whom he is writing a thesis, and to advocate for the decolonization of Africa.

\section{The Tactile Sense and 'Haptic Visuality' in Gomis's Cinema}

Gomis reinforces the narrative depiction of displacement within his three films through aesthetic and technical choices, particularly ones that provoke the auditory and tactile senses of his viewers. Beyond Marks's remark that intercultural cinema is fragmentary, what is of particular relevance for this essay is her understanding of cinematic images as "multisensory," 56 and as such, able to evoke different senses than the visual (which is usually given supremacy in mainstream modern Euro-American societies). ${ }^{57}$ She adopts the notion of 'haptic visuality' to refer to the capacity of the vision to evoke the tactile sense. 'Haptic visuality' is not just characteristic of intercultural cinema, but also of other genres, such as feminist film and video, experimental film, and experimental sexual representations. The experimental style of intercultural cinema is marked by the "need to appeal to embodied knowledge and memory in the absence of other sources." 58 She suggests that embodiment and touch emerge from the "inability to speak" 59 due to the confusion felt by the character who exists between different spaces, that is, in displacement.

Gomis's cinema is characterized by the intimacy of aesthetics where the quest for identity is tackled through the corporeal experience. The visual images in Gomis's films also evoke the tactile sense, forging a 'haptic visuality.' It is often through touch that characters in the film acquire a certain sense of relief, of emplacement. Touch is also suggested when exteriorizing internal tensions. . In Today, the skin contact and the intimacy of the aesthetics are not only illustrated through physical contact between two people but also shown through 
the tangibility of the texture of human flesh. Like Dovey notes in the case of francophone West African exilic films, there are numerous shots of feet, rooting characters to their ground. In Gomis's films, the emplacement of characters is represented not just by feet, but also by different parts of the body. In Today, the texture suggesting the connection and affection between Satché and his children, producing in him a sense of ease, is shown through extreme close-up shots of different parts of the children's bodies. Touch is suggested through these extreme close-up shots of neck wrinkles, feet and hands, slowing down the hectic rhythm that Satché has been feeling on the verge of death, outside in the streets of Dakar. [Sendra_Figure 04]

Connection with others is often stressed through skin contact, affectionate hugs, or sexual encounters. Satché and his wife, Rama, are unable to discuss Satché's situation and their relationship. However, they connect deeply and intimately, unique to them, through different forms of skin contact. This leads to a sense of ease, and thus emplacement, even if only temporarily, that they can only share and express through the intimacy of their bodies in contact. That is, the suggestion of the tactile sense in Gomis's cinema contributes to the reflection on displacement by drawing on forms of temporary emplacement felt while displaced. It reflects, through touch, the dynamic and transformative nature of identity, giving the body a centrality in such transformation, an experience of 'jaam' and hence freedom. Similarly, in As a Man El Hadj's sense of ease and emplacement often arises when establishing skin contact with Myriam, the French artist with whom he develops a relationship. While their relationship is more dialogical than Satché and Rama's in Today, in both films there is a sense of connection and understanding that seems only possible through the tactile sense, flesh contact, and sex.

The tactile sense is also suggested through moments of catharsis in the films. The catharsis operates as a form of relief, through the body, of the tension triggered by the 
realization of the internal struggle. The most evident catharsis appears in As a Man, when El Hadj is showering. These moments imply a willingness to purify oneself, through the purification of the body. They also serve as pauses for reflection, whose repetition evidences the climax of the internal struggle: "How many people lie about the situation in France, work for two or three years, save money, go on holiday, eat well, sleep well, relax... You take a month, get there and you start lying, France, El Dorado, the paradise. Return to France and resume. One year, two years, how many people lie about the situation in France... and repeat. Work like dogs..." El Hadj's monologue refers to the problem of miscommunication between people who have migrated, like him, or who are in a situation of displacement, and those who have remained in the country, like Awa, and his family. They are unable to understand the difficulties encountered by him, yet at the same time, El Hadj, like other displaced people, does not tell the truth about his situation in displacement. Even if they did, the possibility of being understood would be difficult, since there are still many who participate in such lies. His out-spoken feelings are rhythmically unified in crescendo through the sound of water touching his skin, as well as the sound of his hand hitting the wall. It evidences the internal struggle he is experiencing and the transformation due to the situation of displacement, as expressed by Gomis himself: “In the shower, he repeats that people lie and don't tell the truth. But he realizes at the same time that he is falling into the same trap too. That there is something inside himself that is moving; against which he does not manage to struggle. At the end of the day, and wherever you are, the environment will influence you. It makes you a human being and you become someone different. And he struggles to assume that."60 [Sendra_Figure 05]

In Today, the cathartic moment is also associated with a purification of the body, on this occasion through the demonstration by Satché's uncle of how he would wash his body when he died. The purification is figurative in that there is no water, yet the touch of his 
hands on his skin, as a massage, triggers a form of haptic visuality where Satché's relief is sensed. [Sendra_Figure 06] The game between Satché and his children, particularly with his son Ado, jumping on him, and interacting with him physically, through sounds and touch, can also be considered as a moment of catharsis, in which Satché senses relief. The cathartic moments in the films serve to reinforce the importance of the psychological dimension of displacement and the need to reconcile first with the body, the self, in order to be able to experience certain emplacement. That is, the catharsis embodies the alienation experienced by displaced subjects, representing the simultaneous connection and disconnection among the set of relations displacement entails.

The idea of disconnection through touch appears more violently under the form of pain. This operates as a corporeal reflection of the internal struggle, alien-nation and tension provoked by the situation of displacement. Pain is multi-directional in that it can be from the protagonist to himself or towards others. The violence to oneself appears also as a sickness, with El Hadj, in As a Man, feeling stomach pain, embodying the psychological pain that the character struggles to accept; and with Satché, in Today, during moments in which he feels weak and encounters difficulties breathing, as if death were arriving. The pain and feeling of sickness arise in the alienating streets of Paris, in the case of As a Man, or at the market in Dakar, in Today. They usually emerge when characters are feeling lonely, representing that there is no escape from displacement, as this is a psychological state of being which is also reflected externally, in the tangibility of their bodies. [Sendra_Figure 07]

The characters can also engage in violence towards themselves, out of despair. That is the case in As a Man, when El Hadj hits a wall and hurts his hand while he is working. Yet the struggle is internal and it is not solved through those apparent moments of corporeal externalization. The characters' physical violence reaches others as well when the protagonists engage in fights with friends or strangers. In the case of As a Man, El Hadj's 
overwhelming situation due to the expiry of his passport explodes in a bar, at night, under the form of violence against others, which provokes cuts on his face. In Andalusia, outwardlydirected violence arises when Yacine robs a bankand attacks a motorcycle driver in a regretted attempt to steal his vehicle. That is, there is an embodiment of the internal struggle reflective of the psychological state and journey of the characters in displacement. Even if their words cannot express such tension, this is reflected through the body.

\section{The Evoking of Displacement through Silence and Sound}

Gomis's cinema is multisensorial in that vision does not constitute the main narrative element. As Bolgar Smith notes, ${ }^{61}$ film scholarship has often focused on the visual dimension, disregarding the role of the sound in the narrative. If touch serves to reinforce the psychological dimension of displacement, hardly articulated in words, silence and sound further express the internal struggle of the leading characters in Gomis's films. Silence and sound create sonic spaces that are heterotopic and palimpsestic - that is, reflective of the inbetween situation of the characters.

Sound is often a way to evoke home for characters who are in a situation of physical displacement. That is, sonic spaces can lead to micro-home spaces, where characters feel certain comfort even within the hostility of the real site in which they are physically emplaced. As Naficy notes, "home is anyplace; it is temporary and it is moveable; it can be built, rebuilt, and carried in memory and by acts of imagination." ${ }^{92}$ That is, it can also be psychological and remembered through different sounds. In other words, home and comfort can be the result of a sonic space, created through sounds, forging "alternative topographies of the cities." ${ }^{\prime 3}$ That is, one can be home through the aural sense yet be physically located in a place not identified with home. While a combination of sounds can lead to temporary emplacements, it is a remembrance of the situation of displacement. 
In Gomis's cinema, displacement is suggested through a combination of silence (particularly on the part of the predominantly nonverbal characters of Yacine in Andalusia and of Satché in Today), extra-diegetic sound (those added in post-production, in theory, not heard by the characters within the narrative), and very prominently, of intra-diegetic sounds (heard simultaneously by the characters in the film and the spectators). For example, As a Man opens with a series of soundscapes, spaces evoked by sounds, composed of extradiegetic sounds of distortion, which evoke tension or attribute to the scene a dream-like appearance. These combine with a series of intra-diegetic sounds that only later we can locate as past memories of El Hadj. These are not necessarily music, but familiar sounds from the protagonist's past that are associated with 'home,' such as children laughing, the sound of rain, and of the waves from the sea. As the opening credits end, another intra-diegetic sound features in the opening scene - a cassette, in Wolof, that El Hadj is listening to in the privacy and intimacy of his bedroom. The voice on the cassette, which belongs to a relative, structures the epistolary communication as a story, in line with the oral tradition of the country. The displacement, and arguably the nostalgia felt by the character, is evoked from this very first scene.

Similarly, Today opens in the same way that traditional oral tales do, with an interactive call and response structure, in Wolof: "Leboon," to which the people listening to the story reply, "Lippoon," followed by, "Amoon na fi," and so on, in the same way as in English a story would open with the phrase, "Once upon a time..." In Today, this is how the director tells the story of a place where some people know when death comes for certain people. The rootedness in oral tradition in Gomis's films resonates with Mambéty's cinema, as noted by both Dovey and Vlad Dima. In his recent monograph devoted to Mambéty's cinema, Dima focuses on its aural narrative, arguing that "the oral tradition of layered African stories"64 is continued through audio in the films. In her study of francophone West African 
exilic films, Dovey uses the term 'palimpsestic aesthetics,' to refer to the way in which sound can be "turned into a cinematic fabric as tightly woven as images," 65 that can signify at different levels. According to Dima: "Mambéty uses voices, noise and silence as narrative tools that generate their own stories and sonic spaces." 66 He notes that these "sonic spaces" are aural narrative planes created by the manipulation of the sound that constitute precisely the way in which the oral tradition is continued through cinema. Through sound, Dima argues, "Mambéty offers the postcolonial subject and the postcolonial spectator the possibility of reappropriating both a lost space and a complex identity" in films that revolve around physical and mental exiles. ${ }^{67}$ Gomis himself acknowledges Mambéty’s influence on his cinema. In a masterclass at FESPACO in 2017, he claimed: "I did not understand anything I saw, but I was struck by the emotions. As a filmmaker, and from a Senegalese father originally from Guinea Bissau and a French mother, I had the impression of being home." ${ }^{68}$ The statement shows a confluence of Gomis's spectatorship of Mambéty's films and his own filmmaking practices and aesthetics, which set the foundation for his questions of displacement and home through his cinema. Mambéty's films evoked a certain sense of emplacement, that is, rootedness within Gomis, leading to questions about his identity that he would tackle through his films.

Dima attributes two qualities related to sound in Mambéty's films that can also be applied to Gomis's cinema. He defines Mambéty's work as “phantasmagoric," able to create images, which result from a constant dialogue between intra-diegetic and extra-diegetic sound. Sound is phantasmagoric in that it emerges from the imagination, from the psychology of the characters. Dima argues that in Mambéty's films, sound is so important that it can make the image "disappear behind it." ${ }^{\prime 69}$ Similarly, in Gomis's films, the combination of sound and silence are able to immerse us in the subjectivity and psychology of the characters, reflecting their feeling of claustrophobia and confusion, as well as their temporary sense of 
ease and joy. Dima also describes sound as "corporeal," referring to its physicality and its challenge to "traditional cinematic uses of sound and soundtrack" 70 that did not consider the material quality of sound, whose existence depends on whether it is heard by the human ear. ${ }^{71}$ Both sound and silence embody the psychology of the displaced characters in Gomis's films. In short, sound does not create alternative topographies exclusively for the characters in the films, but also, for the spectators of the films, placing us in the characters' subjectivity. This use of sound supersedes the narrative filmic device of the subjective camera and achieves a representation of displacement as a psychological and bodily phenomenon.

Both the sound and subjective camera achieve an internal focalization, putting the spectator in the point of "view" and shifting feelings of the protagonist. The combination of intra-diegetic and extra-diegetic sound, and the use of silence, can suggest home, as mentioned, but they can also serve to reflect the internal struggle and displacement experienced by the characters. Illustrative of this is the overwhelming silence of Satché in Today. He is silent for most of the film. This resounding silence represents his perpetual state of astonishment, of incomprehension. It reinforces that even though he has physically returned to Senegal from the United States, displacement has not been resolved. It is not just felt in relation to his experience abroad, but to Senegal, arguably due to the long period overseas, where 'home' stayed as an idea in the past, and which contrasts with the 'home' where he is in the present.

At times his lack of words silences further intra-diegetic sounds of the environment, disconnecting and abstracting him from them. This happens, for instance, in a scene at the market in Dakar, after his death has been announced. As Satché starts feeling sick and falls down, a crowd approaches him, some helping, others making fun of him. The intra-diegetic sound of the screams by the people is faded out and superposed by an acapella song of female voices. This could be extra-diegetic, that is, added in post-production to increase the 
internal tension for the spectators of the films. Yet it could also be intra-diegetic, heard by Satché as a result of his confusion and his struggle to make sense of himself and the world around him. The scene ends when his friend Sélé arrives to rescue him from the crowd. Satché's inability to express his feelings through words, and his choice to emote through silence, is also evident in an interaction with his friends, where he is unable to respond to the question, "why did you come back?"

The intra-diegetic sounds transport characters to different spaces within the heterotopia of displacement. In As a Man, the tension and alien-nation felt by El Hadj is reflected through the intra-diegetic sound of the sirens of police cars in France. This contrasts with the intra-diegetic pleasant sounds deeply linked to the homeland, which are just in his imagination, such as the waves on the beaches in Dakar, the call to prayer from the mosques, the goats bleating in the streets, or the $\operatorname{sabar}^{72}$ drums.

A large number of interactions, both for Yacine in Andalusia and Satché in Today, happen in silence. It is often when the dialogue starts that miscommunication arises. In Andalusia, when Yacine meets Dounia while she is auditioning at the circus, they end up in Yacine's caravan making love. No words are exchanged. They are connected through skin contact. In contrast, the following day, when they interact verbally, they realize there is no longer a connection between them. "We are not going to be making kids this evening, are we?" Dounia asks. "No," replies Yacine. A similar disconnection through words happens in Today when Satché encounters his ex-girlfriend, Nella, in her art studio. There is a moment of silent interaction, when they are just looking at each other, hiding from each other among the sculptures in the studio, as if playing a children's game. Their communication is through emotions, arguably taking them psychologically to the past, when they had a romantic relationship. Nella asks: "How was life without me?" The dialogue increasingly detaches and 
disconnects the characters until Satché leaves. However, silence further embodies the internal struggle of the characters and the non-closure of displacement.

Gomis's cinema is thus multi-sensorial, and as such, representative of displacement in the twenty-first century. Through Gomis's films, Senegal appears complex, as both a physical and psychological territory, where the dispersion of the population is still tightly linked to the long history of colonization. This is experienced by people of Senegalese heritage both in the country and the diaspora, who sense it through the set of spaces in which they find themselves, both internally and externally, leading to a sense of alien-nation and a quest for identity. This thematic exploration and aesthetic approach make Gomis one of the most emblematic filmmakers participating in the re-appropriation and decolonization of cinema. Akin Adesokan uses the example of Sembène's film and novel entitled Xala, to discuss how "it is individuals, as artists, writers, activists, filmmakers, musicians and so on, who have been able to clearly articulate the problems of postcolonial societies." ${ }^{73}$ For instance, Xala draws on the political problems of a postcolonial Senegal ruled by an ideologically impotent African elite. In this regard, Gomis appears as a filmmaker able to articulate the situation left by the traces of postcolonialism in the twenty-first century, where displacement is rooted in a colonial past that manifests itself in a variety of ways. Inspired by Mambéty, and rooted in the prolific filmic heritage of Senegal, Gomis's cinema also transcends the postcolonial specificities of his father's country, tackling the universal theme of the human condition in a unique way that has earned him international recognition. This essay offers a foundation for the study of his multi-sensorial style, suggesting that displacement is an endless condition, that can be experienced and temporarily relieved through the tactile and the aural senses. This essay further shows that the rich Senegalese filmic heritage is continued today through productions both from filmmakers in the country, and from 'rooted cosmopolitans' who are physically based abroad, yet who are internally 
simultaneously in Senegal. Gomis's work constitutes an excellent example of the potential of the current period for African filmmakers to tell their own stories, decolonizing the gaze, thanks to the technological opportunities of the digital era and internationalization, diversifying funding, production, and distribution. He embodies the revitalisation of Senegalese film culture, with a cinema that places individuals at the heart of the decolonization struggle, through an intimate approach and psychological focus reflective of the complex set of relations in which people find themselves in Senegal and, more broadly, on the African continent, and in the world.

Author: Estrella Sendra is a third-year PhD candidate at SOAS, University of London, in the Department of African Languages and Cultures. After a year of fieldwork in Senegal, she is currently writing her thesis on festivals in Senegal, with the International Festival of Folklore and Percussion (FESFOP) of Louga as the main case study. Originally from Spain and with background in Film Studies and Journalism, she has also made a number of documentary films on migration from Senegal to Spain and cultural aspects of Senegal. Her documentary Témoignages de l'autre côté was awarded the European Charlemagne Youth Prize for Spain (2012). She directed the Cambridge African Film Festival in 2014 and 2015 and has been involved in other African film festivals in the UK and Spain, such as the African Film Festival of Tarifa-FCAT, where she was the head of the international media office in 2013. Besides her academic publications on African film and Cultural Studies, she is a regular contributor to Wiriko, an online platform on African Arts and Cultures in Spanish. She also writes in the cultural section of Senegalese newspaper Le Soleil, where she worked in summer 2012. For more info: www.estrellasendra.com 
${ }^{1}$ This is the first francophone film to receive the Best African Film award. The film received five other awards.

${ }^{2} \mathrm{He}$ is the director of three multi-awarded short films, Tourbillons (dir. Alain Gomis, 1999, 13 min.), Petite Lumière (dir. Alain Gomis, 2003, 15 min.) and Ahmed (dir. Alain Gomis, 2006, 24 min.); and four multi-awarded feature length films; L'Afrance (dir. Alain Gomis, 2001, 90 min.), Andalucia (dir. Alain Gomis, 2007, 90 min.), Tey (dir. Alain Gomis, 2012, 86 min.) and Félicité (dir. Alain Gomis, 2017, $123 \mathrm{~min}$.); and script-writer of the documentary Cuba, an African odyssey (dir. Jihan El-Tahri, 2007, 118 min.).

${ }^{3}$ Olivier Barlet's film review of Tey / Today (dir. Alain Gomis, 2012), published in Black Camera 5, no. 1 (2013): 263-264, is a translation by Melissa Thackway of an article published in Africultures: Olivier Barlet, "Aujourd'hui (Tey). D'Alain Gomis", Africultures, October, 10, 2012, www.africultures.com/aujourdhui-tey-11069. Kate Bolgar Smith's thesis is entitled Soundtracks of the City: Listening to the Film Music of the Black Diaspora in London and Paris. [London], 2015:10-12. It examines soundtracks of films that address black diasporic life in London and Paris, where she refers to the importance of sound and silence in Tey.

${ }^{4}$ While L'Afrance has been translated as As a Man, the original title is a play on the words $L$ 'Afrique (Africa) and La France (France). It suggests an in-between position between the two. Yet, at the same time, it makes reference to the A-France, that is, the "no France," shedding light on the hostility at the country that contrasts the common idealist view of it. ${ }^{5}$ Lindiwe Dovey, "Subjects of exile: Alienation in Francophone West African cinema." International Journal of Francophone Studies 12, no. 1 (April 2009): 55-75.

${ }^{6}$ Lindiwe Dovey, "Subjects of exile: Alienation in Francophone West African cinema." International Journal of Francophone Studies 12, no. 1 (April 2009): 56.

${ }^{7}$ Lindiwe Dovey, "Subjects of exile: Alienation in Francophone West African cinema." International Journal of Francophone Studies 12, no. 1 (April 2009): 4.

${ }^{8}$ Ousmane Sembène, Idrissa Ouedraogo (from Burkina Faso) and Abderrahmane Sissako studied and developed their film careers outside of the continent in the former Soviet Union and France.

${ }^{9}$ Lindiwe Dovey, "Subjects of exile: Alienation in Francophone West African cinema." International Journal of Francophone Studies 12, no. 1 (April 2009): 57-59.

${ }^{10}$ Julia Kristeva, Strangers to Ourselves, New York / London: Harverster Wheatsheat, 1991.

${ }^{11}$ Olivier Barlet and Melissa Thackway, "Tey / Today by Alain Gomis (review)." Black Camera 5, no. 1 (2013): 264.

12 I prefer this term to Naficy's "cosmopolitan homeless" (Hamid Naficy, Home, Exile, Homeland: Film, Media and the Politics of Place. New York; London: Routledge, 1999:4) as it stresses the psychological dimension of the idea of home, as a root, even if intangible and while living a nomadic lifestyle across the world.

${ }^{13}$ Kwame Anthony Appiah, The Ethics of Identity. Princeton, N.J. ; Oxford: Princeton University Press, 2005: 213-273.

${ }^{14}$ Kwame Anthony Appiah, The Ethics of Identity. Princeton, N.J. ; Oxford: Princeton University Press, 2005: 213.

${ }^{15}$ Kwame Anthony Appiah, The Ethics of Identity. Princeton, N.J. ; Oxford: Princeton University Press, 2005: 241.

${ }^{16}$ Following the success of Félicité at Berlinale and FESPACO, two of the most prestigious film festivals in the world, Macky Sall met with Alain Gomis in March 2017 to congratulate him on the award. The film had been partially funded by the Fonds de Promotion à l'Industrie Cinématographique et Audiovisuelle (FOPICA), established for the first time in 2002. 
${ }^{17}$ Despite the limited number of cinemas in the country, Alain Gomis has been screening his films at cultural venues, and exchanged with the film community in Senegal, for instance, at the school of cinema located in Parcelles Assainies, Cinébanlieue, organiser of the Banlieue Film Festival. When the new cinema Canal Olympia Téranga was opened in May 2017, Alain Gomis's film Felicité was programmed for the opening week. This shows that he is committed to "give back" to Senegal by sharing his film production with the country.

${ }^{18}$ Hamid Naficy, An Accented Cinema: Exilic and Diasporic Filmmaking. Princeton; Oxford: Princeton University Press, 2001: 3-4.

${ }^{19}$ Olivier Barlet "Félicité, une leçon de cinéma," Africultures, February 27, 2017, www.africultures.com/felicite-une-lecon-de-cinema-13987

${ }^{20}$ Gomis in Oliver Barlet 'La masterclass d'Alain Gomis au Fespaco 2017', Africultures, March 14, 2017, www.africultures.com/la-masterclass-dalain-gomis-au-fespaco-2017-14024

${ }^{21}$ Hamid Naficy, An Accented Cinema: Exilic and Diasporic Filmmaking. Princeton; Oxford: Princeton University Press, 2001: 20.

${ }^{22}$ Laura Marks, The Skin of the Film: Intercultural Cinema, Embodiment, and the Senses. Durham: Duke University Press, 2000: 2.

${ }^{23}$ Laura Marks, The Skin of the Film: Intercultural Cinema, Embodiment, and the Senses. Durham: Duke University Press, 2000: 1.

${ }^{24}$ Laura Marks, The Skin of the Film: Intercultural Cinema, Embodiment, and the Senses. Durham: Duke University Press, 2000: 24.

${ }^{25}$ Interview with the director during Film Africa 2013, London. Emphasis added by Estrella Sendra.

${ }^{26}$ Kate Bolgar Smith, Soundtracks of the City: Listening to the Film Music of the Black Diaspora in London and Paris. [London], 2015:10-12.

${ }^{27}$ Lindiwe Dovey,"Subjects of exile: Alienation in Francophone West African cinema." International Journal of Francophone Studies 12, no. 1 (April 2009): 65.

${ }^{28}$ Laura Marks, The Skin of the Film: Intercultural Cinema, Embodiment, and the Senses. Durham: Duke University Press, 2000: xi.

${ }^{29}$ Olivier Bakewell, 'Conceptualising Displacement and Migration: Processes, Conditions and Categories' in Koser, K., \& Martin, S., The migration-displacement nexus: Patterns, processes, and policies. New York: Berghahn Books, 2011: 14-22.

${ }^{30}$ Oliver Bakewell 'Conceptualising Displacement and Migration: Processes, Conditions and Categories' in Koser, K., \& Martin, S., The migration-displacement nexus: Patterns, processes, and policies. New York: Berghahn Books, 2011: 22.

${ }^{31}$ Olivier Bakewell, 'Conceptualising Displacement and Migration: Processes, Conditions and Categories' in Koser, K., \& Martin, S., The migration-displacement nexus: Patterns, processes, and policies. New York: Berghahn Books, 2011: 23.

${ }^{32}$ Ibid.

${ }^{33}$ June Givanni, Symbolic Narratives / African Cinema. London: British Film Institute, 2001: 65.

${ }^{34}$ Stuart Hall, "Who needs 'Identity"” in Stuart Hall \& P. du Gay (eds) Questions of Cultural Identity, London: Thousand Oaks, Calif.: Sage Publications, 1996: 2 \& Ernesto Laclau. New Reflections On the Revolution of Our Time: Ernesto Laclau. London; New York: Verso, 1990: 92.

${ }^{35}$ Ernesto Laclau. New Reflections On the Revolution of Our Time: Ernesto Laclau. London; New York: Verso, 1990: 92.

${ }^{36}$ Angelika Bammer (ed.), Displacements: Cultural Identities in Question. Bloomington: Indiana University Press, 1994: xi - xii. 
${ }^{37}$ Dovey suggests that "in spite of the racist attitudes he experiences as an immigrant in France, the protagonist of L'Afrance ultimately chooses to make it his home" (Dovey, 59). Yet the expiry date of its passport is the trigger to realize that it is not exactly its home.

${ }^{38}$ Hamid Naficy, Home, Exile, Homeland: Film, Media and the Politics of Place. New York; London: Routledge, 1999: 3.

${ }^{39}$ Michel Foucault, 'Of Other Spaces: Utopias and Heterotopias,' 1986 [1967]. In The Visual Culture Reader, e. Nicholas Mirzoeff (London and New York: Routledge, 2002[1998]: 229236.

${ }^{40}$ Michel Foucault, 'Of Other Spaces: Utopias and Heterotopias,' 1986 [1967]. In The Visual Culture Reader, e. Nicholas Mirzoeff (London and New York: Routledge, 2002[1998]: 229.

${ }^{41}$ This contrasts with the view of life as measured only by the time, but needs to be seen as interrelated with it. Michel Foucault, 'Of Other Spaces: Utopias and Heterotopias,' 1986 [1967]. In The Visual Culture Reader, e. Nicholas Mirzoeff (London and New York:

Routledge, 2002[1998]: 231.

42 Ibid.

${ }^{43}$ Ibid.

${ }^{44}$ Olivier Barlet and Melissa Thackway, "Tey / Today by Alain Gomis (review)." Black Camera 5, no. 1 (2013): 263.

${ }^{45}$ Ibid.

${ }^{46}$ Lindiwe Dovey, "Subjects of exile: Alienation in Francophone West African cinema." International Journal of Francophone Studies 12, no. 1 (April 2009): 59.

${ }^{47}$ Vlad Dima, Sonic space in Djibril Diop Mambéty's films, Bloomington: Indiana University Press, 2017:11.

${ }^{48}$ This was re-used again, after being abandoned for a long time, in the 2016 Biennale de l'art contemporaine de Dakar (Dak'Art).

49 The elected president was Macky Sall, which was perceived by the population as a democratic victory, highly shaped by the emergence and action of Y'En A Marre. Senegalese filmmaker Rama Thiaw's multi-award winning documentary The Revolution Won't Be Televised (dir. Rama Thiaw, 2015) is devoted to such protests and two of their leaders, Senegalese rappers from the group Keur Gui. For a film review read Estrella Sendra, The Revolution Won't Be Televised, 2015, 110 minutes. Wolof and French (with English subtitles). Senegal. Bull Falle Images (review), African Studies Review, vol. 60, no. 1 (2017): 248-250.

${ }^{50}$ Lindiwe Dovey, "Subjects of exile: Alienation in Francophone West African cinema." International Journal of Francophone Studies 12, no. 1 (April 2009): 57.

${ }^{51}$ This play-on-words is borrowed from Lindiwe Dovey, "Subjects of exile: Alienation in Francophone West African cinema." International Journal of Francophone Studies 12, no. 1 (April 2009).

52 This is the Wolof word for peace, referring to a kind of peace that starts from the interior, the peace with oneself, and that is highly symbolic of Senegalese culture.

${ }^{53}$ Interview with the director during Film Africa 2013, London. Emphasis added by Estrella Sendra.

${ }^{54}$ Sarah Jilani, 'Writing Exile: Displacement and Arrival in Eva Hoffman's Lost in Translation and Edward Said's Out of Place, Life Writing, 12:1, 2015:60.

${ }^{55}$ Hamid Naficy, Home, Exile, Homeland: Film, Media and the Politics of Place. New York; London: Routledge, 1999:3.

${ }^{56}$ Laura Marks, The Skin of the Film: Intercultural Cinema, Embodiment, and the Senses. Durham: Duke University Press, 2000:xi.

${ }^{57}$ Laura Marks, The Skin of the Film: Intercultural Cinema, Embodiment, and the Senses. Durham: Duke University Press, 2000:xiii. 
${ }^{58}$ Laura Marks, The Skin of the Film: Intercultural Cinema, Embodiment, and the Senses. Durham: Duke University Press, 2000: 8.

${ }^{59}$ Laura Marks, The Skin of the Film: Intercultural Cinema, Embodiment, and the Senses. Durham: Duke University Press, 2000: 21.

${ }^{60}$ Interview with the director during Film Africa 2013, London.

${ }^{61}$ Kate Bolgar Smith, Soundtracks of the City: Listening to the Film Music of the Black Diaspora in London and Paris. [London], 2015.

${ }^{62}$ Hamid Naficy, Home, Exile, Homeland: Film, Media and the Politics of Place. New York ; London: Routledge, 1999: 5-6.

${ }^{63}$ Kate Bolgar Smith, Soundtracks of the City: Listening to the Film Music of the Black Diaspora in London and Paris. [London], 2015: 8.

${ }^{64}$ Vlad Dima, Sonic space in Djibril Diop Mambéty's films, Bloomington: Indiana University Press, 2017:1.

${ }^{65}$ Lindiwe Dovey,"Subjects of exile: Alienation in Francophone West African cinema." International Journal of Francophone Studies 12, no. 1 (April 2009): 66.

${ }^{66}$ Vlad Dima, Sonic space in Djibril Diop Mambéty's films, Bloomington: Indiana University Press, 2017:1.

${ }^{67}$ Vlad Dima, Sonic space in Djibril Diop Mambéty's films, Bloomington: Indiana University Press, 2017:1-5.

${ }^{68}$ Gomis in Oliver Barlet 'La masterclass d'Alain Gomis au Fespaco 2017', Africultures, March 14, 2017, www.africultures.com/la-masterclass-dalain-gomis-au-fespaco-2017-14024 ${ }^{69}$ Vlad Dima, Sonic space in Djibril Diop Mambéty's films, Bloomington: Indiana University Press, 2017: 2.

${ }^{70}$ Vlad Dima, Sonic space in Djibril Diop Mambéty's films, Bloomington: Indiana University Press, 2017:1.

${ }^{71}$ Vlad Dima, Sonic space in Djibril Diop Mambéty's films, Bloomington: Indiana University Press, 2017: 21.

${ }^{72}$ Sabar drums are played with one hand and one stick, and are traditional drums in Senegal, mainly played by Serer and Wolof people, yet today, by many people from different ethnicities in the country.

${ }^{73}$ Akinwumi Adesokan, Postcolonial Artists and Global Aesthetics, Bloomington: Indiana University Press, 2011: 2. 